\title{
Правила для авторов
}

В журнал «Вестник Российской военно-медицинской академии» принимаются статьи и сообщения по наиболее значимым вопросам учебной и учебно-методической, научной и научно-практической, лечебно-профилактической и клинической работы.

Работы для опубликования в журнале должны быть представлены в соответствии с данными требованиями.

1. Статья должна быть напечатана на одной стороне листа размером A4, с полуторными интервалами между строчками, со стандартными полями (слева - 3 см, справа - 1 см, сверху и снизу - 2,5 см), с нумерацией страниц (сверху в центре, первая страница без номера). Страницы должны быть пронумерованы последовательно, начиная с титульной. Статья должна быть подписана всеми авторами.

2. Присылать следует 1 распечатанный экземпляр и электронный вариант на CD-диске. Текст необходимо печатать в редакторе Word любой версии, шрифтом Times New Roman, 14 кеглем, без переносов.

3. Объем обзорных статей не должен превышать 20 страниц машинописного текста, оригинальных исследований, исторических статей - 10.

4. В начале первой страницы указываются универсальный десятичный код (УДК), инициалы и фамилия автора и название статьи (на русском и английском языках), наименование кафедры или лаборатории и учреждения, где выполнена работа, телефонный номер и электронный адрес автора, ответственного за связь с редакцией.

5. Первая страница должна содержать резюме на русском и английском языках (объемом не менее 200 и не более 250 слов). В резюме должны быть изложены основные результаты, новые и важные аспекты исследования или наблюдений. Резюме не должно содержать аббревиатур. Далее должны быть приведены ключевые слова на русском и английском языках (8-10 слов).

6. Текст статьи должен быть тщательно выверен и не содержать орфографических, грамматических и стилистических ошибок.

7. Особенно тщательно следует описывать материалы и методы исследования, точно указывать названия использованных реактивов, фирму изготовителя и страну.

8. Если в статье имеется описание наблюдений на человеке, не используйте фамилии, инициалы больных или номера историй болезни, особенно на рисунках или фотографиях. При изложении экспериментов на животных укажите, соответствовало ли содержание и использование лабораторных животныхправилам, принятым в учреждении, рекомендациям национального совета по исследованиям, национальным законам.

9. Иллюстрации должны быть четкие, контрастные. Цифровые версии иллюстраций должны быть сохранены в отдельных файлах в формате Tiff, с разрешением не менее $300 \mathrm{dpi}$, размером не менее $5 \times 5 \mathrm{~cm}$ и последовательно пронумерованы. Иллюстрации и подрисуночные подписи должны быть размещены в основном тексте. Перед каждым рисунком, диаграммой или таблицей в тексте обязательно должна быть ссылка. В подписях к микрофотографиям, электронным микрофотографиям обязательно следует указывать метод окраски и обозначать масштабный отрезок. Диаграммы должны быть представлены в исходных файлах.

10. Библиографические ссылки в тексте должны даваться цифрами в квадратных скобках в соответствии со списком литературы в конце статьи. В начале списка в алфавитном порядке указываются отечественные авторы, затем - иностранные, также в алфавитном порядке.

11. Библиографическое описание литературных источников должно соответствовать требованиям ГОСТ 7.1-2003 «Библиографическая запись. Библиографическое описание документа. Общие требования и правила составления».

\section{Примеры:}

\section{Книга с одним автором}

Небылицин, В.Д. Избранные психологические труды / В.Д. Небылицин. - М.: Педагогика, 1990. - 144 с.

\section{Книга с двумя авторами}

Корнилов, Н.В. Травматологическая и ортопедическаяпомощь в поликлинике: руководство для врачей / Н.В. Корнилов, Э.Г. Грязнухин. - СПб.: Гиппократ, 1994. - 320 с.

\section{Книга с тремя авторами}

Иванов, В.В. Анализ научного потенциала / В.В. Иванов, А.С. Кузнецов, П.В. Павлов. - СПб.: Наука, 2005. - 254 С.

\section{Книга с четырьмя авторами и более}

Алисиевич, В.Н. Теория зарубежной судебной медицины: учеб. пособие / В.Н. Алисиевич [и др.]. - М.: Изд-во МГУ, 1990. -40 c.

\section{Автореферат диссертации}

Еременко, В.И. О Центральных и периферических механизмах сердечно-сосудистых нарушений при длительном эмоциональном стрессе: автореф. дис. ... д-ра мед. наук / В.И. Еременко. - СПб.: ВМА, 1997. - 34 с. 


\section{Из сборника}

Михайленко, А.А. Хламидийные инфекции: гематоэнцефалический игистогематический барьеры / А.А. Михайленко, Л.С. Онищенко // Актуальные вопр. клиники, диагностики и лечения : тезисы докл. науч. конф. - СПб.: ВМА, 1999. - С. 284.

Жуковский, В.А. Разработка, производство и перспективы совершенствования сетчатых эндопротезов для пластической хирургии / В.А. Жуковский // Материалы 1-й междунар. конф. «Современные методы герниопластики и абдоминопластики с применением полимерных имплантатов». - М.: Наука, 2003. - С. 17-19.

\section{Глава или раздел из книги}

Зайчик, А.Ш. Основы общей патофизиологии / А.Ш. Зайчик, Л.П. Чурилов // Основы общей патологии: учеб. пособие для студентов медвузов. - СПб.: ЭЛБИ, 1999. - Ч. 1., гл. 2. - С. 124-169.

\section{Из журнала}

Жукова, М.В. Особенности церебральной гемодинамики у пациентов с мальформацией Киари I типа / М.В. Жукова [ и др.] // Вестн. Росс. воен.-мед. акад. - 2011. - № 1 (33). - C. 50-55.

\section{Из газеты}

Фомин, Н.Ф. Выдающийся ученый, педагог, воспитатель / Н.Ф. Фомин, Ф.А. Иванькович, Е.И. Веселов // Воен. врач. - 1996. - № 8 (1332). - С. 5.

Фомин, Н.Ф. Выдающийся ученый, педагог, воспитатель / Н.Ф. Фомин, Ф.А. Иванькович, Е.И. Веселов // Воен. врач. - 1996. - 5 сент.

\section{Статья из продолжающегося издания}

Линденбратен, А.Л. Опыт использования процессуального подхода к оценке качества медицинской помощи / А.Л. Линденбратен // Бюллетень НИИ соц. гигиены, экон. и упр. здравоохранением. - 1993. - Вып. 1. - С. 36-45.

\section{Патент}

Пат. № 2268031 Российская Федерация, МПКА61Н23.00. Способ коррекции отдаленных последствий радиационного воздействия в малых дозах / М.А. Карамуллин, А.Н. Шутко, А.Е. Сосюкин и др.; опубл. 20.01.2006, Бюлл. № 02. - С. 22-25.

\section{2. Статья должна сопровождаться:}

- направлением руководителя организации в редакцию журнала;

- экспертным заключением о возможности опубликования в открытой печати.

13. Не допускается направление в редакцию работ, напечатанных в других изданиях или уже отправленных в другие редакции.

14. Редакция имеет право вести переговоры с авторами по уточнению, изменению, сокращению рукописи.

15. Рукописи, оформленные не в соответствии с правилами, к публикации не принимаются.

16. Присланные материалы по усмотрению редколлегии направляются для рецензирования членам редакционного совета.

17. Принятые статьи публикуются бесплатно. Рукописи статей авторам не возвращаются. 